\title{
Occurrence of Methyl tert-Butyl Ether (MTBE) in Public and Private Wells, Rockingham County, New Hampshire
}

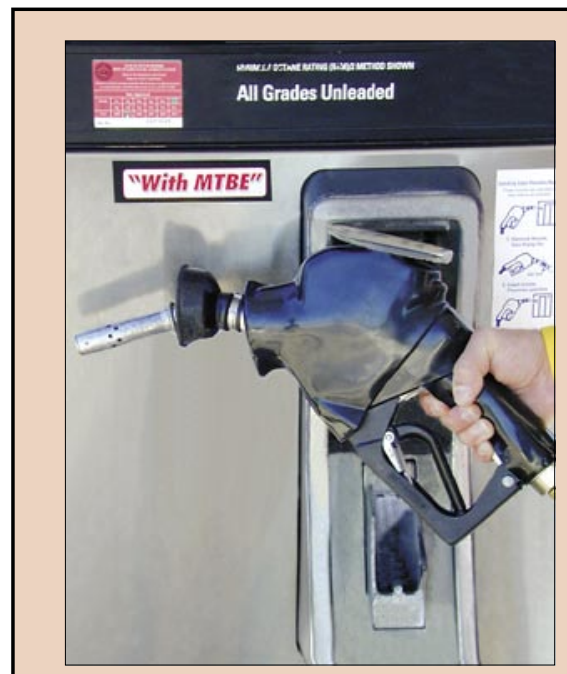

\section{Major Findings:}

- MTBE was detected at concentrations greater than 0.2 micrograms per liter $(\mu \mathrm{g} / \mathrm{L})$ in 40 percent of 120 public wells and 21 percent of 103 private wells sampled.

- MTBE concentrations were greater in relatively deep public wells with low water yields.

- MTBE concentrations in wells were strongly related to urbanization.

- MTBE concentrations in public wells decreased with distance from underground gasoline storage tanks.

\section{INTRODUCTION}

Methyl tert-butyl ether (MTBE) has been added to gasoline since the late 1970s to increase octane and reduce vehicle emissions. Its use significantly increased with the production of reformulated gasoline (RFG) after amendments to the Clean Air Act in 1990 required the use of cleaner burning fuels. MTBE has relatively high solubility in water, low soil adsorption, and is slowly biodegraded. Thus, once it has been released to the environment through spills, leaking storage tanks, or other pathways, it has the potential for pervasive and persistent contamination of ground water. Although no Federal drinking-water standard has been established for MTBE, the U.S. Environmental Protection Agency (USEPA) (1997) has tentatively classified the compound as a possible carcinogen and has set a drinking-water advisory at 20 to 40 micrograms per liter $(\mu \mathrm{g} / \mathrm{L})$. The State of New Hampshire (2000) has adopted a maximum contaminant level of $13 \mu \mathrm{g} / \mathrm{L}$ for MTBE in drinking water.

Routine monitoring by the New Hampshire Department of Environmen- tal Services (NHDES) indicates that the presence of MTBE in public water-supply wells, at or above a detection level of $0.5 \mu \mathrm{g} / \mathrm{L}$, has increased statewide from 12.7 percent in 2000 to 15.1 percent in 2002, and that occurrence is greatest in the four New Hampshire counties where use of reformulated gasoline is required (fig. 1). In Rockingham County, MTBE occurrence rates increased from 20.3 to 23.1 percent during the same period.

The potential risk of exposure to MTBE through drinking water in New Hampshire may be greatest in Rockingham County. This County has the second largest population in the state $(280,500)$ and the largest population served by ground water $(57,000$ by community ground-water systems, 135,000 by private wells, and 71,000 by community systems that use a combination of surface and ground water). In this region, heavy reliance on ground water for domestic and public supply adds urgency to understanding the occurrence of, and controls on, MTBE contamination. This Fact Sheet summarizes the major findings from a cooperative study between the
U.S. Geological Survey (USGS) and the NHDES on the occurrence of MTBE in public and private wells used for drinking water in Rockingham County (Ayotte and others, 2004). These findings may have implications for future water-resources management in New Hampshire and other areas with similar hydrogeologic settings.

\section{STUDY DESIGN}

To accurately determine the occurrence and distribution of MTBE, this study incorporated a random sampling design and a lower analytical detection level $(0.2 \mu \mathrm{g} / \mathrm{L})$ than had previously been used in the state. Between May and August 2003, a total of 223 samples were collected from drinking-water sources, including 120 samples from public wells

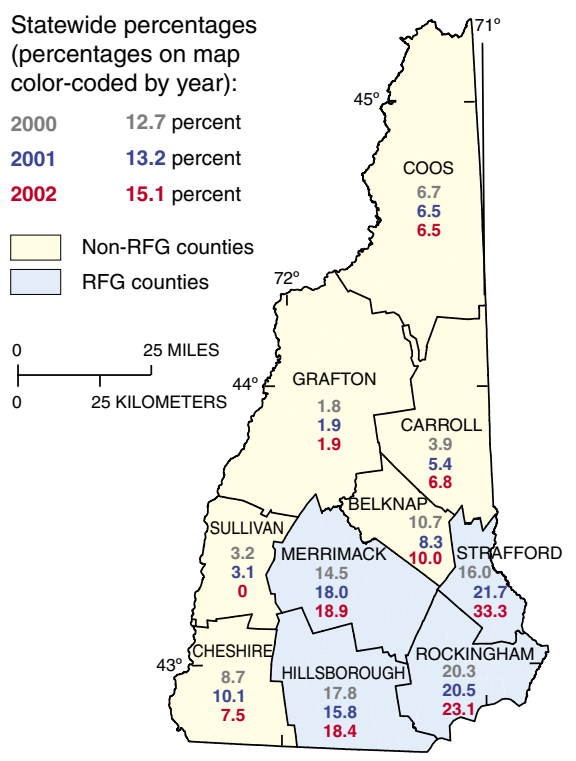

Figure 1. Percent of public water-supply wells with MTBE concentrations greater than or equal to 0.5 microgram per liter by county for 2000, 2001, and 2002, showing counties where reformulated gasoline (RFG) is and is not required. 

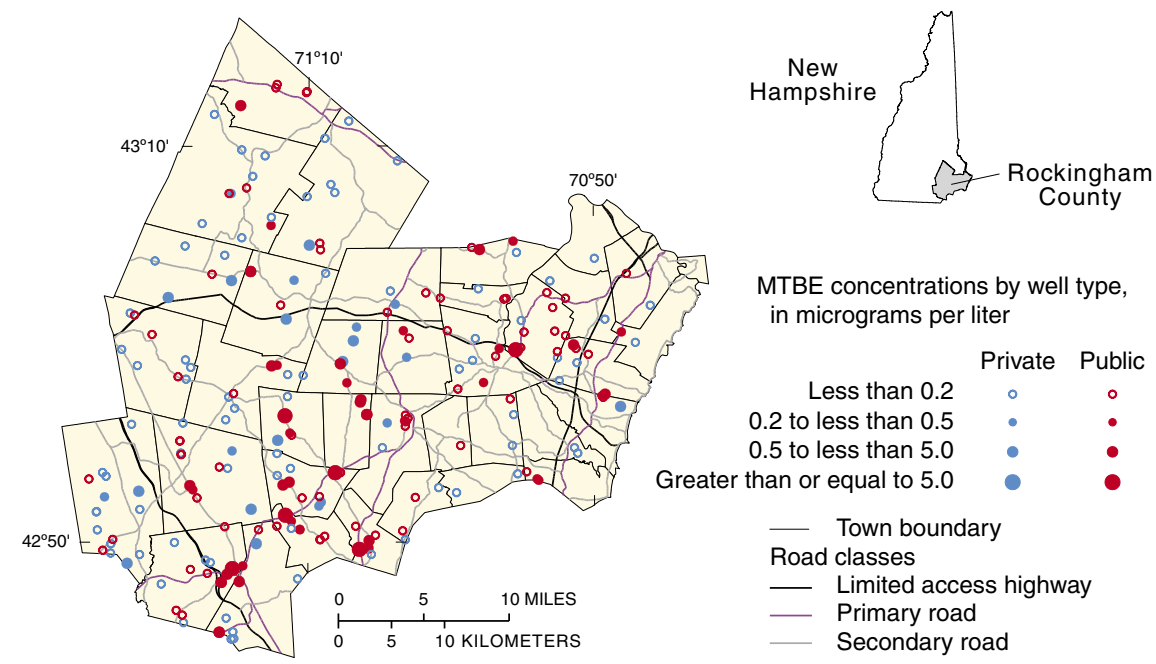

MTBE concentrations by well type, in micrograms per liter

Less than 0.2
0.2 to less than 0.5
0.5 to less than 5.0
Greater than or equal to 5.0
Town boundary
Road classes
$\quad$ Limited access highway
$\quad$ Primary road
$\quad$ Secondary road

Figure 2. Concentrations of MTBE in public and private water-supply wells in Rockingham County, New Hampshire, during 2003.

and 103 samples from private domestic wells (fig. 2). All of the private wells were in the fractured-bedrock aquifer and, of the public wells, 98 were in the bedrock aquifer and 22 were in unconsolidated deposits.

Samples were collected, preserved, and stored according to USGS protocols (Koterba and others, 1995; Ayotte and others, 2004). Samples were analyzed at the NHDES Laboratory according to a modification of USEPA (1995) method 524.2. Several types of quality-control samples, representing 15.2 percent of the total samples, also were collected. A number of standard statistical analyses were used to evaluate the data and assess possible relations between MTBE occurrence and various factors, including aquifer type (bedrock or unconsolidated deposits); bedrock geology; public water-system size; water-supply establishment type; reported well yield; well depth; population; land use; soils; roads; well proximity to underground gasoline storage tanks (USTs); and water-sample temperature, $\mathrm{pH}$, specific conductance, and dissolved oxygen.

\section{MTBE OCCURRENCE}

The locations of sampled wells and associated MTBE concentrations are shown in figure 2. MTBE was found, at concentrations higher than the detection level of $0.2 \mu \mathrm{g} / \mathrm{L}$, in 40 percent of the public wells and 21 percent of the private wells sampled. These rates are higher than those reported in a study of Maine counties where reformulated gasoline was used (State of Maine, 1998). The range of concentrations found is shown in figure 3. Public wells had significantly greater occurrence rates and higher concentrations of MTBE than private wells (table $1)$. None of the private wells had a concentration that exceeded either the state drinking-water standard of $13 \mu \mathrm{g} / \mathrm{L}$ or the state action level of $5 \mu \mathrm{g} / \mathrm{L}$ for notification of adjacent well owners. However, four public wells exceeded both these levels. In all four cases, well owners had prior knowledge of the contamination and treatment systems were in place to remove MTBE.

The rates of MTBE occurrence in public wells in fractured bedrock and unconsolidated deposits were 41.8 and 31.8 percent, respectively (table 1). However, differences in occurrence rates and concentrations were not significantly different between the two aquifers. Public wells that were used for residential supply, including wells at apartment complexes, condominiums, and mobile home parks, had the highest rate of occurrence, with 63.1 percent above $0.2 \mu \mathrm{g} / \mathrm{L}$. This rate was significantly higher than that for wells at schools (20.5 percent), but not significantly higher than that for wells at commercial establishments (40.7 percent) or large community systems $(31.3$ percent). Although occurrence rates were not significantly different among system categories, community water systems (that serve at least 15 year-round service connections or 25 year-round residents) had the highest rate at 52.8 percent, followed by transient noncommunity systems (that do not serve over 25 of the same people for at least 6 months per year) and nontransient, noncommunity systems (that serve more than 25 of the same people for more than 6 months per year but are not community supplies), which had rates of 34.6 and 26.8 percent, respectively.

\section{FACTORS RELATED TO MTBE OCCURRENCE}

MTBE concentrations in samples from private wells were related to a number of urban factors including population density, housing density, and the percentages of urban land use and roads within 1,640 feet (500 meters) of the well. In addition, MTBE concentrations were related to the specific conductance of the water sample. Because specific conductance can increase due to chloride from road salt and septic systems, it also is an indicator of urbanization.

Relations between MTBE occurrence in public wells and various factors are shown in figure 4. MTBE concentrations were strongly related to urban indicators such as population density, housing density, and specific conductance of the water sample. Concentrations declined with distance to underground gasoline storage tanks, which is consistent with findings from another New Hampshire study where gasoline sources, within the source-water protection area of public wells, were related to MTBE concentrations (Moyer and others, 2002).

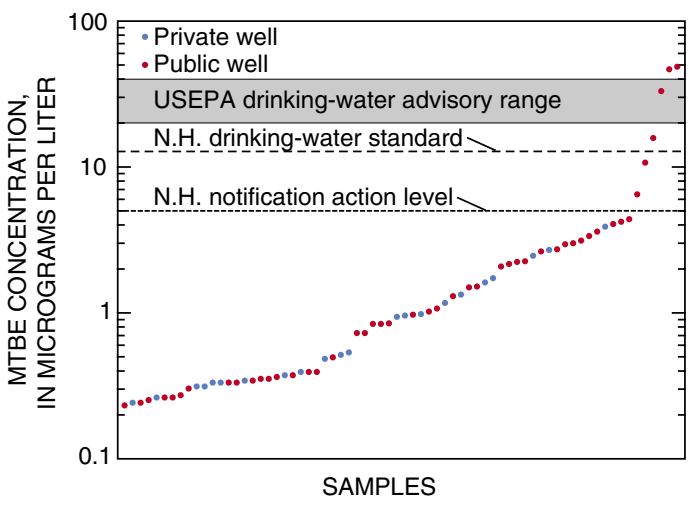

Figure 3. Range of MTBE concentrations measured above a detection level of 0.2 micrograms per liter by well type, Rockingham County, New Hampshire. (N.H. is New Hampshire; USEPA is U.S. Environmental Protection Agency). 
Table 1. MTBE detection frequency by well type, publicsupply establishment type, and public-system category.

[ $\mu \mathrm{g} / \mathrm{L}$, micrograms per liter; MTBE, methyl tert-butyl ether]

\begin{tabular}{|l|c|c|}
\hline \multicolumn{2}{|c|}{ Well/aquifer type } \\
\hline $\begin{array}{c}\text { Number of } \\
\text { samples }\end{array}$ & $\begin{array}{c}\text { Percent of wells } \\
\text { with MTBE } \\
\text { concentrations } \\
\text { higher than } \\
\mathbf{0 . 2} \mathbf{~} \mathbf{g} / \mathbf{L}\end{array}$ \\
\hline Private (all bedrock) & 103 & 21.4 \\
\hline Public & 120 & 40.0 \\
\hline Bedrock Public-supply establishment type \\
\hline Unconsolidated deposits & 38 & 61.8 \\
\hline \multicolumn{3}{|c|}{ Public-system category } \\
\hline Residences & 53 & 31.8 \\
\hline Commercial & 27 & 40.7 \\
\hline Schools/recreation & 39 & 20.5 \\
\hline $\begin{array}{l}\text { Large community systems } \\
\text { (serving at least 1,000 } \\
\text { people) }\end{array}$ & 16 & 31.3 \\
\hline \multicolumn{3}{|c|}{52.8} \\
\hline Community & 26 & 34.6 \\
\hline Transient noncommunity & 41 & 26.8 \\
\hline Nontransient noncommunity & \\
\hline
\end{tabular}

MTBE concentrations in public wells increased significantly with well depth and, although not statistically significant, concentrations were generally lower in wells with high reported yields. In interpreting these findings, it is important to understand common well-drilling practices and trends in the region. Depths for all public wells sampled in this study ranged from 16 to $1,020 \mathrm{ft}$, with a median of $226 \mathrm{ft}$. Eighty-two percent of the public wells were in the bedrock aquifer and ranged in depth from 125 to $1,020 \mathrm{ft}$. During bedrock-well installation, drilling is typically continued until an adequate supply of water is obtained, either through increased yield or increased well storage. Therefore, lowyielding wells are often relatively deep. In response to increasing demands for water in the rapidly developing regions of New Hampshire, bedrock wells are being drilled deeper and mean well depth has increased from $326 \mathrm{ft}$ in 1985 to $409 \mathrm{ft}$ in 1998 (Drew and others, 2001).

Deep, low-yielding wells could exhibit high occurrence rates and concentrations of MTBE through various processes. In low-yielding wells, a major proportion of the water and MTBE contamination may be derived from leakage of shallow ground water, either through fractures near the bedrock surface or along the well casing. Alternatively, low-yielding wells may require relatively large contributing areas to achieve an adequate yield, and thus have a greater chance of intercepting MTBE contamination. Einarson and Mackay (2001) note that contaminant concentrations in wells under constant pumping decrease with increasing pumping rate because the ratio of clean water to contaminated water increases. Thus, for deep, low-yielding bedrock wells, MTBE that enters the well is less likely to be diluted than in high-yielding wells.

MTBE concentrations in public wells were significantly higher in water samples that were more acidic (lower $\mathrm{pH}$ ). Ayotte and others (2003) found that in bedrock wells in eastern New England, the pH of well water is related to the estimated age of the recharge water to the well. The implication is that recently recharged (low $\mathrm{pH}$ ) ground water is more directly connected to the land surface and, thus, to sources of MTBE. Conversely, ground water with high $\mathrm{pH}$ levels may be relatively old and, in some cases, could predate the introduction of MTBE into the local ground-water system.

\section{SOURCES OF MTBE CONTAMINATION}

Moran and others (2004) suggest that concentrations greater than $20 \mu \mathrm{g} / \mathrm{L}$ of MTBE in ground water are likely a result of point-source contamination from relatively large leaks and spills, but lower concentrations could be the result of either point sources or non-point sources, such as evaporative losses from tanks and pipelines, incomplete combustion in engines, and urban stormwater runoff from areas with small leaks and spills. For public wells in Rockingham County, the highest MTBE concentrations may be related to point sources, as indicated by the observed relation between MTBE concentrations and distance from underground storage tanks. Subsurface releases of MTBE vapor, associated with gasoline vapor recovery systems, have been investigated (Young and Golding, 2002; Lynn, 2004). However, the extent to which this source of contamination occurs in Rockingham County is not known. The observed relation between MTBE occurrence in wells and various urban indicators may reflect a combination of sources, including leaking tanks, the cumulative effects of minor spills, and the urban atmosphere. Pankow and others (1997) show that urban atmospheric sources alone, in areas of high net ground-water recharge such as in New England, could produce concentrations of MTBE in ground water that are similar to those found at low levels in this study.

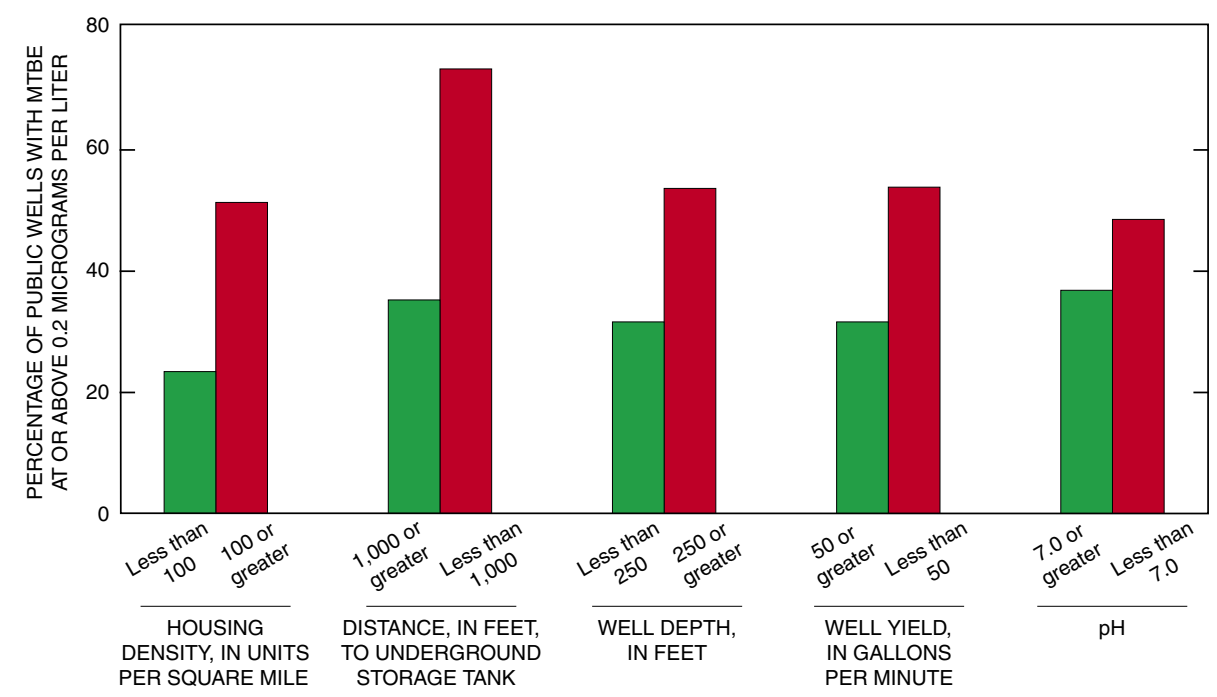

Figure 4. MTBE occurrence in public wells related to housing density, distance to nearest underground gasoline storage tank (UST), well depth, well yield and $\mathrm{pH}$ of the water sample, Rockingham County, New Hampshire. 


\section{CONCLUSIONS}

In Rockingham County, population growth continues at a rapid rate and there is an increasing demand for ground water from bedrock aquifers. Frequently, relatively deep wells, with high well-storage volumes and relatively low yield, are used to meet this demand. Such wells may have large contributing areas and a greater chance of capturing MTBE contamination than shallower wells with a similar yield. The bulk of the water entering such wells may be derived from shallow fractures directly connected to overburden materials where MTBE contamination may be present. In low-yielding wells it is less likely that intercepted MTBE would be diluted with large volumes of clean water. The combination of urbanization, reformulated gasoline usage, aquifer characteristics, and the use of deep, low-yielding wells could have important implications for the occurrence of MTBE in drinking-water supplies in this region.

\section{ACKNOWLEDGMENTS}

The authors thank the many private citizens and operators of public-water systems who participated in this study, Patricia Bickford and the staff of the New Hampshire Department of Environmental Services Laboratory who provided analyses of water samples, and Jocelyn Knowles and Camille Partin for their assistance in water sampling.

\section{REFERENCES}

Ayotte, J.D., Argue, D.M., and McGarry, F.J., in press, MTBE occurrence and related factors in public and private wells in southeast New Hampshire: Environ. Sci. and Technol., ASAP Web release, November 13, 2004, DOI: 10.1021/es049549e.

Ayotte, J.D., Montgomery, D.L., Flanagan, S.F., and Robinson, K.W., 2003, Arsenic in ground water in eastern New England: Occurrence, controls, and human health implications: Environmental Science and Technology, v. 37, p. 2075-2083.

Drew, L.J., Schuenenmeyer, J.H., Armstrong, T.R., and Sutphin, D.M., 2001, Initial yield to depth relation for water wells drilled into crystalline bedrock, Pinardville Quadrangle, New
Hampshire: Ground Water, v. 39, p. 676-684.

Einarson, M.D., and Mackay, D.M., 2001, Predicting the impacts of ground water contamination: Environmental Science and Technology, v. 35, p. 67A-73A.

Koterba, M.T., Wilde, F.D., and Lapham, W.W., 1995, Ground-water data-collection protocols and procedures for the National Water-Quality Assessment Program-collection and documentation of water-quality samples and related data: U.S. Geological Survey Open-File Report 95-399, 113 p.

Lynn, Gary, 2004, Tracking troubling vapor releases in New Hampshire: New England Interstate Water Pollution Control Commission LUSTline Bulletin 47, June 2004, accessed July 25, 2004, at http://www.neiwpcc.org PDF_Docs/l_line47.pd], p. 13-30.

Moran, M.J., Zogorski, J.S., and Squillace, P.J., 2004, Occurrence and implications of methyl tert-butyl ether and gasoline hydrocarbons in ground water and source water in the United States and in drinking water in 12 northeast and mid-Atlantic states, 1993-2002: U.S. Geological Survey Water-Resources Investigations Report 03-4200, 26 p.

Moyer, E.E., Erickson, J.A., and McGarry, F.J., 2002, Correlation of MTBE detections in New Hampshire public water systems with documented potential petroleum sources: Contaminated Soil, Sediment, and Water, July/August 2002, p. 23-26.

Pankow, J.F., Thompson, N.R., Johnson, R.L., Baehr, A.L., and Zogorski, J.S., 1997, The urban atmosphere as a nonpoint source for the transport of MTBE and other volatile organic compounds (VOCs) to shallow groundwater: Environmental Science and Technology, v. 31, p. 2821-2828.

State of Maine, 1998, The presence of MTBE and other gasoline compounds in Maine's drinking water: Augusta, Maine, $15 \mathrm{p}$.

State of New Hampshire, 2000, Code of Administrative Rules: Concord, N.H., Env-Ws 317.01(b).

U.S. Environmental Protection Agency, 1997, Drinking water advisory-consumer acceptability advice and health

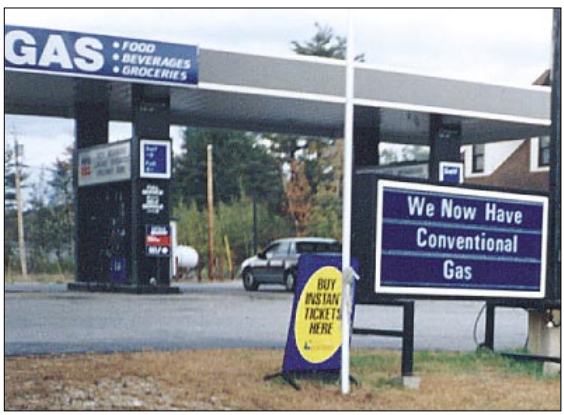

Advertisement in a jurisdiction where reformulated gasoline (RFG) is no longer required.

effects on Methyl Tertiary-Butyl Ether (MTBE): EPA-882-F-97-009, 34 p.

U.S. Environmental Protection Agency, 1995, Methods for determination of organic compounds in drinking water, Supplement III, EPA-600/R-95/131.

Young, T.M., and Golding, R.D., 2002, Underground storage tank system field-based research project report: Davis, Calif., California State Water Resources Control Board, 22 p.

-By Joseph D. Ayotte', Brian R. Mrazik', Denise M. Argue', and Frederick J. McGarry ${ }^{2}$

${ }^{1}$ U.S. Geological Survey.

${ }^{2}$ New Hampshire Department of Environmental Services.

\section{FOR ADDITIONAL INFORMATION:}

The data for this study are available at:

U.S. Geological Survey

New Hampshire/Vermont District

361 Commerce Way

Pembroke, NH 03275

(603) 226-7800 Phone

(603) 226-7894 FAX

Copies of this report can be purchased from:

U.S. Geological Survey

Branch of Information Services

Box 25286

Denver Federal Center

Denver, CO 80225-0286

Visit USGS and NHDES Web sites at:

http://nh.water.usgs.gov

http://www.usgs.gov

http://www.des.state.nh.us/ 